\title{
Isolation and characterization of microsatellite loci in two non-native hydromedusae in the San Francisco Estuary: Maeotias marginata and Moerisia sp.
}

\author{
Mariah H. Meek • Melinda R. Baerwald • \\ Alpa P. Wintzer · Bernie May
}

Received: 18 June 2009/Accepted: 25 June 2009/Published online: 7 July 2009

(c) The Author(s) 2009. This article is published with open access at Springerlink.com

\begin{abstract}
We characterized 10 new microsatellite markers in each of two species of hydromedusae, Maeotias marginata and Moerisia sp. Genetic diversity was estimated using 20-41 individuals collected from Suisun Marsh within the San Francisco Estuary, CA. Allelic richness ranged from 5-9 in M. marginata and 2-10 in Moerisia sp. with average expected heterozygosities of 0.71 and 0.57 respectively. One locus in M. marginata and two in Moerisia sp. deviated from Hardy-Weinberg equilibrium expectations, likely due to null alleles.
\end{abstract}

Keywords Hydrozoa - Jellyfish - Oligos ·

San Francisco Estuary

Two species of hydromedusae, Maeotias marginata and Moerisia sp., native to the Ponto-Caspian region, have become established in the San Francisco Estuary, CA (SFE). Non-native jellyfish and other hydroids can have severe effects on the ecosystems they invade as many are voracious predators, consuming large amounts of prey and disrupting planktivorous food webs (Purcell and Arai 2001). Additionally, jellyfish blooms are increasing globally (Mills 2001) and can directly affect fish populations by devouring massive quantities of eggs and larvae and decreasing fish survival through competition for resources (Purcell and Arai 2001; Purcell et al. 2001; Purcell 2003; Lynam et al. 2005).

M. H. Meek ( $\square) \cdot$ M. R. Baerwald · B. May

Department of Animal Science, University of California,

One Shields Ave, Davis, CA 95616, USA

e-mail:mhmeek@ucdavis.edu

A. P. Wintzer

Center for Watershed Sciences, University of California,

One Shields Ave, Davis, CA 95616, USA
The brackish water hydrozomedusae studied herein are novel predators in the SFE and, thus, have an especially high likelihood of impacting this system and competing with juvenile fish (Moyle and Light 1996). Very little is known about the basic biology and life history of these invaders. Microsatellite markers characterized for these species will allow us to investigate population structure and genetic diversity, as well as determine reproductive strategies and life history characteristics of these potentially important non-natives.

We collected the medusae phase of $M$. marginata and Moerisia sp. from Suisun Marsh in the SFE. We extracted whole genomic DNA from bell tissue of $M$. marginata and entire individuals of Moerisia sp., due to their small size, using Qiagen's Gentra Puregene Kit protocol. Genetic Identification Services constructed, screened, and sequenced four libraries enriched with the following repeat motifs: (1) GATA, (2) CCAT and CTGT, (3) ATG, AAC, and ATT, and (4) a mix of all tetra-nucleotide repeats available, using pooled DNA from both species and according to the procedures of Meredith and May (2002). A total of 381 clones were sequenced.

We analyzed sequences using SEQUENCHER version 4.7 (Gene Codes Corporation) and used MREPS version 2.5 (Kolpakov et al. 2003) to identify repeat regions. Once repeat loci were located, we employed PRIMER 3 (Rozen and Skaletsky 2000) to create primer pairs flanking each region of interest. We then tested primer pairs on 2-10 individuals of each species to assess microsatellite amplification and level of polymorphism.

Some primer pairs worked best with Promega GoTaq Flexi DNA polymerase, while others worked better with Roche FastStart Taq DNA polymerase. The recipe for those with Promega Taq was $2 \mu \mathrm{l} 5 \times$ Promega Buffer, $0.8 \mu \mathrm{l}$ of $10 \mu \mathrm{M}$ dNTPs, $0.6 \mu \mathrm{l}$ of $25 \mu \mathrm{M} \mathrm{Mg}, 0.08 \mu \mathrm{l}$ 


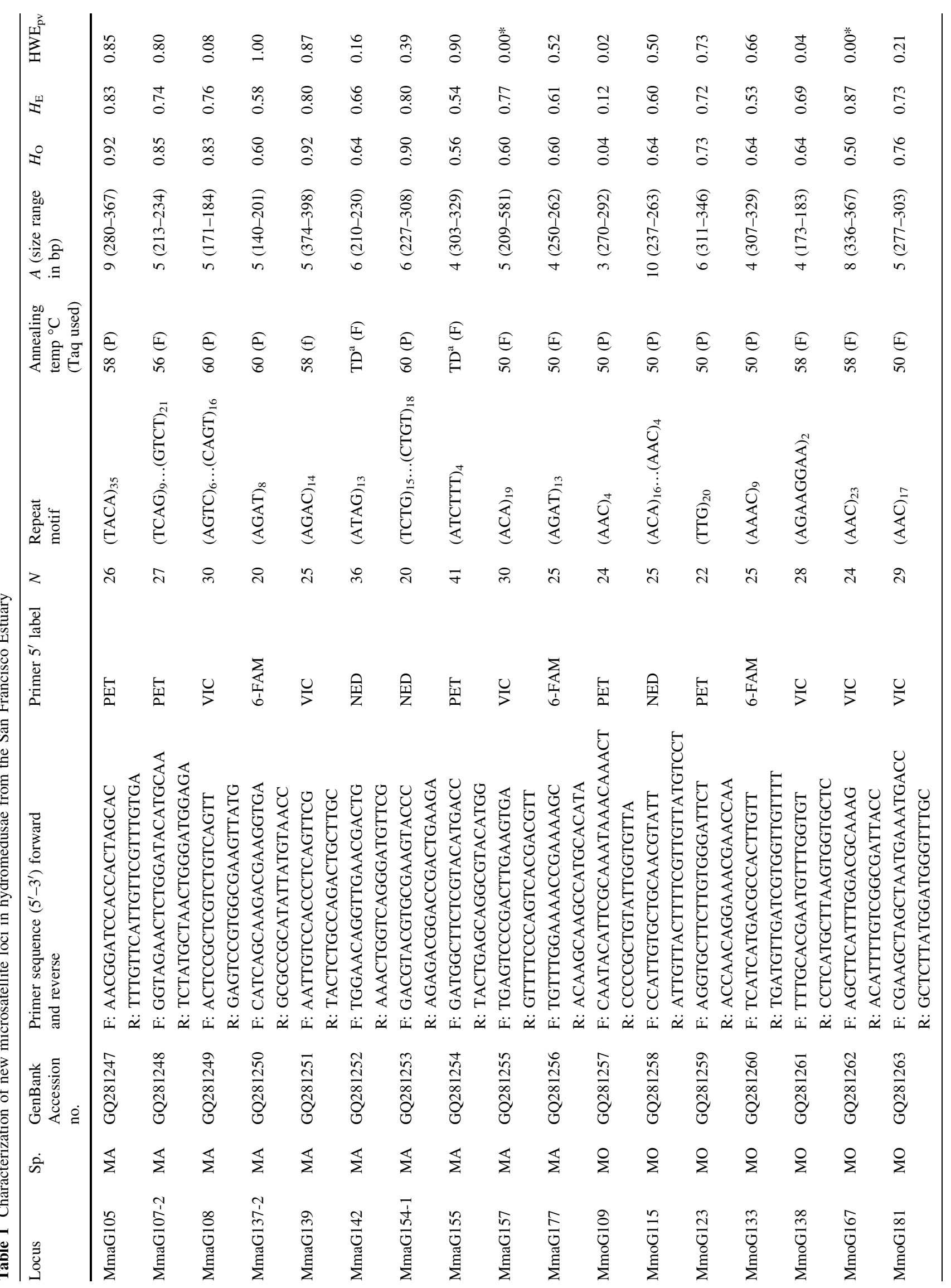


Promega Taq, and $0.4-0.7 \mu \mathrm{l}$ of each $1 \mu \mathrm{M}$ primer. The recipe for PCRs run with FastStart Taq was $1 \mu \mathrm{l} 10 \times$ FastStart Buffer (with $\mathrm{MgCl}_{2}$ ), $0.8 \mu \mathrm{l}$ of $10 \mu \mathrm{M}$ dNTPs, $0.3 \mu \mathrm{l}$ FastStart Taq, and $0.4-0.7 \mu \mathrm{l}$ of each $1 \mu \mathrm{M}$ primer, with the exception of primers MmoG167 which were used at $5 \mu \mathrm{M}$. For all reactions, enough water was added to bring the total reaction volume up to $10 \mu \mathrm{l}$. All PCRs were performed using a Bio-Rad DNA Engine Dyad thermal cycler using the following cycling parameters: $95^{\circ} \mathrm{C}$ for $5 \mathrm{~min}$, and 30 cycles of $94^{\circ} \mathrm{C}$ for $30 \mathrm{~s}$, various annealing temperatures for $30 \mathrm{~s}$ (See Table 1), and $72^{\circ} \mathrm{C}$ for $1 \mathrm{~min}$, followed by $60^{\circ} \mathrm{C}$ for $45 \mathrm{~min}$, and held at $10^{\circ} \mathrm{C}$. Loci were screened by diluting PCR products $1: 1$ with $98 \%$ formamide loading buffer, denaturing at $95^{\circ} \mathrm{C}$ for $3 \mathrm{~min}$, and separating PCR products on a $5 \%$ denaturing polyacrylamide gel at $50 \mathrm{~W}$. We visualized the gel by overlaying with SYBR-Green-agarose following the protocol of Rodzen et al. (1998) and scanning with a GE Healthcare Fluorimager 595.

Ten for each species of the 71 loci screened were polymorphic and well-resolved in the initial screening. These loci were then characterized with additional individuals to bring the total to a minimum of 20 individuals screened (Table 1). This characterization was completed by adding a $5^{\prime}$ fluorescent label (NED, VIC, and PET from Applied Biosystems, 6-FAM from Integrated DNA Technologies) to the forward primer. One $\mathrm{ml}$ of labeled PCR product was added to $8.8 \mu \mathrm{l}$ of highly deionized formamide (Gel Company) and $0.2 \mu$ lof LIZ600 size standard (ABI) and run on an ABI 3130xl Genetic Analyzer. We used GENEMAPPER version 4.0(ABI) to visualize and score fragments. None of the loci amplified for both species.

Expected and observed heterozygosities were calculated using GENETIC DATA ANALYSIS (Lewis and Zaykin 2001) and Genepop (Raymond and Rousset 1995) was used to evaluate for Hardy-Weinberg equilibrium (HWE) using Fisher's exact test with 100,000 permutations and removal of missing data. Summary of the microsatellite loci are presented in Table 1. Number of alleles per locus ranged from 5-9 in M. marginata and 210 in Moerisia sp. with average expected heterozygosities of 0.71 and 0.57 , respectively. One locus in M. marginata and two in Moerisia sp. deviated from HWE expectations. This is likely due to the presence of null alleles since observed heterozygosities were lower than expected for all three loci.

The microsatellite loci described here will be used to conduct future genetic studies investigating the invasion biology of these hydrozoans.

Acknowledgements We thank CALFED Science Program Grant \#1036, NOAA Dr. Nancy Foster Scholarship, UC Davis Jastro- 
Shields Research Scholarship, and US National Science Foundation grant NSF-DGE \#0114432 IGERT UC Davis for financial support. We are grateful to Dr. Peter Moyle, Nicole Elen, Jessica Petersen, and John Durand for assistance and encouragement during this project.

Open Access This article is distributed under the terms of the Creative Commons Attribution Noncommercial License which permits any noncommercial use, distribution, and reproduction in any medium, provided the original author(s) and source are credited.

\section{References}

Kolpakov R, Bana G, Kucherov G (2003) mreps: efficient and flexible detection of tandem repeats in DNA. Nucleic Acids Res 31: 3672-3678

Lewis PO, Zaykin D (2001) GENETIC DATA ANALYSIS (GDA): Computer Program for the Analysis of Allelic Data. http://hydro dictyon.eeb.uconn.edu/people/plewis/software.php

Lynam CP, Hay SJ, Brierley AS (2005) Jellyfish abundance and climatic variation: contrasting responses in oceanographically distinct regions of the North Sea, and possible implications for fisheries. J Mar Biol Assoc UK 85:435-450

Meredith EP, May BP (2002) Microsatellite loci in the Lahontan tui chub, Gila bicolor obesa, and their utilization in other chub species. Mol Ecol Notes 2:156-158
Mills CE (2001) Jellyfish blooms: are populations increasing globally in response to changing ocean conditions? Hydrobiologia 451:55-68

Moyle PB, Light T (1996) Biological invasions of fresh water: empirical rules and assembly theory. Biol Conserv 78:149-162

Purcell JE (2003) Predation on zooplankton by large jellyfish, Aurelia labiata, Cyanea capillata and Aequorea aequorea, in Prince William Sound, Alaska. Mar Ecol Prog Ser 246:137-152

Purcell JE, Arai MN (2001) Interactions of pelagic cnidarians and ctenophores with fish: a review. Hydrobiologia 451:27-44

Purcell JE, Shiganova TA, Decker MB, Houde ED (2001) The ctenophore Mnemiopsis in native and exotic habitats: US estuaries versus the Black Sea basin. Hydrobiologia 451: $145-176$

Raymond M, Rousset F (1995) Genepop (Version-1.2)—populationgenetics software for exact tests and ecumenicism. J Hered $86: 248-249$

Rodzen JA, Agresti JJ, Tranah G, May BP (1998) Agarose overlays allow simplified staining of polyacrylamide gels. Biotechniques 25:584

Rozen S, Skaletsky HJ (2000) PRIMER3 on the WWW for general users and for biologist programmers. In: Krawetz S, Misener S (eds) Bioinformatics methods and protocols: methods in molecular biology. Humana Press, Totowa, NJ, pp 365-386 